\title{
OLDER PEOPLE IN THE INFORMATION SOCIETY
}

\author{
ALEKSANDRA MARCINKIEWICZ-WILK \\ Faculty of Pedagogy, University of Wrocław, \\ ul. J. W. Dawida 1, Wrocław, Poland \\ E-mail address: aleksandra.marcinkiewicz@uwr.edu.pl
}

\begin{abstract}
:
This paper focuses on the situation of older people in the information society. In the theoretical part of article phenomena of ageing population and information society are described. This paper includes results of a qualitative research. The data was collected with the use of the biographical method. The method for data processing was qualitative content analysis. In the research, two older and educationally active people took part.

Results of research show how older people understand the information society and what risks and opportunities they notice in this new reality. Narratives of the respondents indicate that education is of crucial importance for participation in the information society. Older people who take part in the lifelong learning cope better with the new reality than people who do not learn.

Drawing on the results of the research, we can point out areas of education which should be development. Moreover, it is visible that educational activity of older people is very important in adaptation to the information society. Narratives of seniors indicate reasons for the lack of educational activity in other seniors. Accordingly, it can be specified what actions should be undertaken to prevent the exclusion of older people in this new reality.
\end{abstract}

Key words: Information Society, seniors, older people, ageing society.

\section{INTRODUCTION}

Contemporary times are characterized by the rapid pace of change caused by the development of information technology. Therefore, ageing populations are facing a modern phenomenon called "The Information society" and education is its main pillar. The dynamic of change in the information society is causing knowledge and skills to become outdated. Therefore, continuous updating of knowledge is necessary. Modern man needs to be prepared for lifelong learning because education is a way which allows us to adapt to this changing reality. 
Keeping up with changes of the information society is a challenge for modern man. The present reality is not stable or predictable, so familiar patterns of behaviour do not work well in new situations. The Information society is also called a society of young people, because the people who grew up surrounded by new technologies are more eager to keep up with the changes.

Older people, on the other hand, face another reality, given that they grew up in completely different times. The lack of key skills in the information society can be a reason for social marginalization. This issue is important, because parallel with changes associated with the creation of the information society, we are dealing with a progressive ageing of the population in developed countries. In connection with the growing number of seniors in the community, the problem of marginalization of this group of people in information society is the new reality. Solving this problem is one of the priorities of European Union and, for this reason, it is worth researching how seniors perceive the information society. This paper undertakes this issue.

\section{THE PHENOMENON OF AGEING POPULATION}

The progressive aging of the population is a fact that applies to industrial countries. The number people aged over sixty years old has risen from $8 \%$ in 1950 to $12 \%$ in 2013. Moreover, in 2050 people of older age will rise to 2 billion, which is $20 \%$ of all population (World Population Ageing, 2013, p. 11). Therefore, the problem of ageing population is one of the most important in the modern world.

When thinking about ageing population it is important to highlight demography. A comparison between the death rate and reproduction is also key because the survival of the species hangs on this. Halting repeated disasters of mortality between the XVI and XVII century, and a significant lengthening of the human life span caused the spectre of doom to be averted (Stuart-Hamilton, 2006, pp. 13-14).

The theory of demographic transition is fundamental to the understanding of the process of population ageing. According to the theory, demographic transition is the replacing of a population with radical, lasting and irreversible drop in morality and rise in fertility by a population with a low intensity of this process (Coldwell, 2006, pp. 307-309). Western European countries first reached a state in which reproductive success is free from the risks associated with uncontrolled mortality. It was expected that the reduction of mortality to a biological minimum and reaching the state of simple replacement of generations would be sustainable. However, despite the biological and social stability, modern societies are far from reproductive success (Okólski, 1997, pp. 25-55).

United Nations considers a society old when people over 60 years old represent $7 \%$ of all population. The age of a society is determined as follows (Nowak-Starz, Markowska, Zboina, \& Grzywna, 2009, pp.17-19): 
- the young society - less than $4 \%$ of people aged over 65 years in the overall structure of this society;

- the mature society - 4 to $7 \%$;

- more than $7 \%$ of this society exceeds the threshold of old age demographics;

- more than $10 \%$ this society, which exceeds the threshold of advanced age demographic.

In Poland, according to the Central Statistical Office (GUS), in 2014 the number of residents aged 65 and above accounted for $14.7 \%$ of the population (Rocznik Demograficzny, 2015, p. 58). According to the criteria set by the UN, it is clear that Poland has exceeded the threshold of advanced age demographic. Therefore, action should be taken to care for the elderly, because they are exposed to marginalization, especially in the information society.

\section{INFORMATION SOCIETY}

The information society is defined as the risk society. Risk accompanies man forever, because " risk is an indispensable feature of practical and cognitive activities" (Kozielecki, 1987, p. 132). However, the rapid development of technology transforms the physical and spiritual world for mankind. The dynamic of change happens so quickly that it is often defined as potential danger. In opinion of Piotr Sztompka, the phenomenon of risk in the information society has a different quality than before, because "first of all, in the forefront risk is not in the context of the natural environment, but the environment or technical civilization, created by man. We live in a world of "manufactured risk" that is the price of civilization and technical progress" (Sztompka, 2002, pp. 576-577). Therefore, the postindustrial society is accompanied by fear of what it entails. The sense of fear and insecurity is thus an inseparable part of contemporary reality.

Literature often points out the risks that the information society entails. The risk should be seen both through the prism of globalization, and the personal point of view of each individual, as a member of society. That way, we can talk about challenges of information society; challenges which contain risks (dangers) and possibilities (Euczak, 2011, p. 400). Sources of challenges include: modernization, development of new technologies and the globalization process. Based on a literature analysis of the new information society (Marcinkiewicz, 2014, pp179-183), we can point out challenges faced man living in the new reality, such as:

- ability to use new technology - this challenge stems from the technical aspect of a society where these skills are essential for the proper functioning of the new society;

- counteraction e-exclusion of older people - people without key skills 
in the information society are vulnerable to marginalization and exclusion, so it is necessary to implement educational efforts to counteract this process;

- ability to adapt to the constantly changing conditions of life - due to the fast dynamics of changes in new society;

- the need to constantly improve skills and update of knowledge - continuous learning is necessary to keep up with the rapid obsolescence of knowledge;

- change in the nature of work - work would be flexible, fragmented, often carried out through new technologies (on-line) (see: Castells, 2008, p. 203-334). Work would be adapted to the specific needs of older workers;

- virtuality of the world - it is one of the characteristics of society. Virtual space is an important element of human life, as more and more aspects of his life go online;

- process of the ageing of the population - this is the effect of demographic transition, which causes profound changes in quantitative and structural population;

- a new type of communication - this is the result of the dominance of indirect contacts (internet, mobile) over the direct (face to face).

It should be noted that among the listed challenges within the information society there are both risks and opportunities. Moreover, these characteristics of the information society correspondent to categories distinguished in the empirical part (risks vs. opportunities). It is a base to create research on the understanding of the information society by seniors. It should be noted that the comprehensiveness of technology and the growing importance of information implies the necessity for specialized skills and knowledge. Therefore, in the new reality very important is idea of lifelong learning. This idea has been recognized by the European Union as a pillar of the information society. People who take part in education better cope with challenges of modern reality.

\section{METHODOLOGY OF RESEARCH}

The research was conducted in the interpretative paradigm in qualitative strategy. This paradigm postulates understanding subjective aspects of seniors' world. It allows us to show a way of understanding and interpreting of the information society by seniors. The biographical method was used in research, which is focused on the interpretation made through dialogue (Dominicé, 2006, p. 27 ).

The aim of this research was to get more understanding of how older people interpret the information society. Another aim is to know what challenges of 
information society are noticed by seniors. 12 people ${ }^{1}$ took part in this research (4 men and 8 women) aged over 60 years old. Each of the individuals was informed about the aim of research and the method used to conduct it.

The method for data processing was a qualitative analysis of content. The first step of research was collecting and preparing the data for research, which was obtained using the biographical method. The next step was to define the unit of analysis in the form of full statements of participants of research. Then, to develop categories and a coding scheme which were used to code all the text, and finally interpret data and conclusions (Kubinowski, 2011, pp. 235-424).

In this study, an open and selective coding was used. The first step of the analysis was to read the empirical data which was used to distinguish categories. Scheme 1 shows the relation between categories. The intentional selection of people to research was used. The main goal of the selection was chosen people over 60 year old who are educationally active. Criteria of the educational activity corresponds to the importance the idea lifelong learning in the modern society.

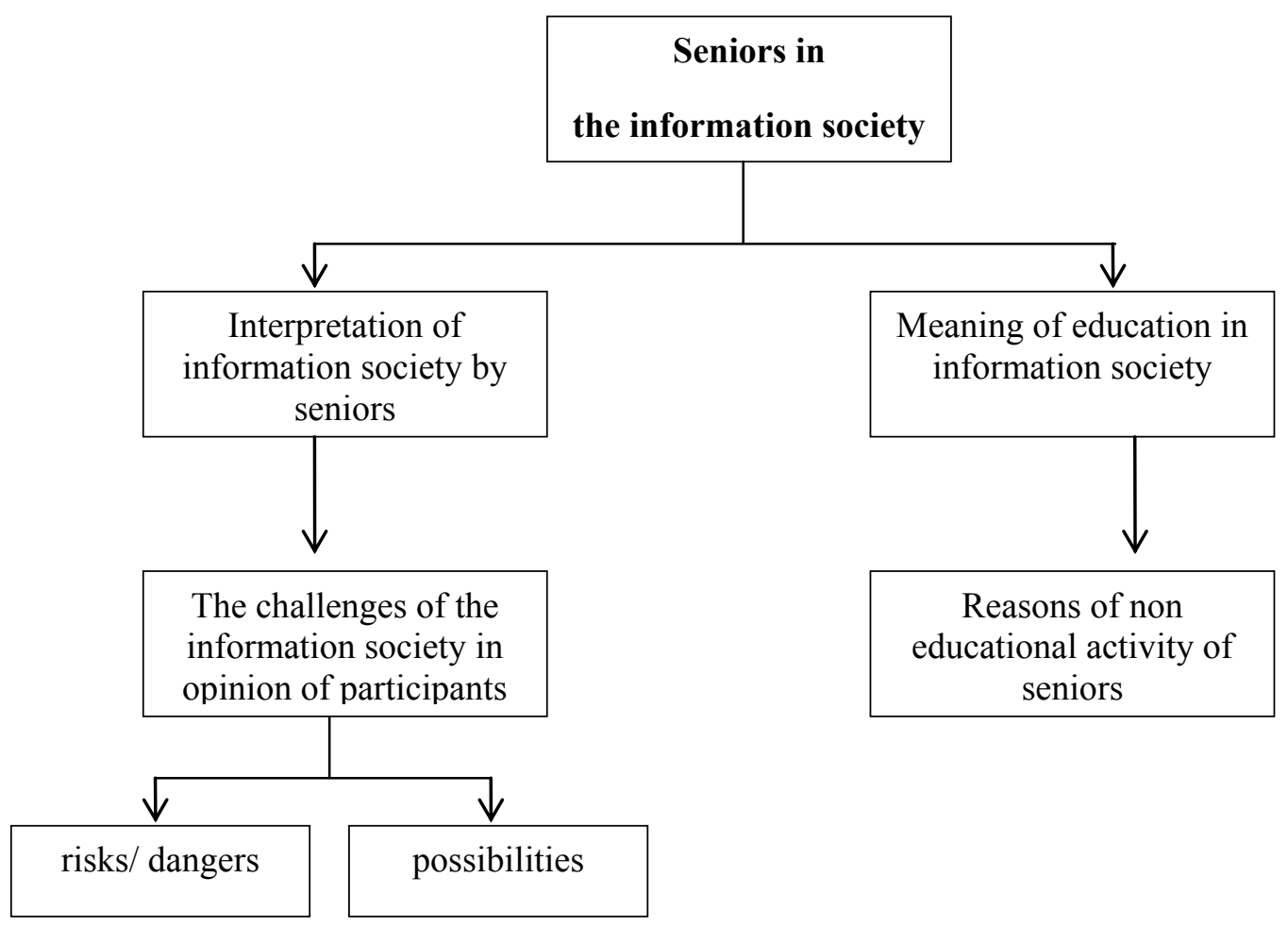

\section{Figure 1. Relation between categories}

Sources: author

1 Narrator 1: man, 65 years old, teacher, higher education; Narrator 2: woman, 65 years old, language tutor, higher education; Narrator 3: man, 69 years old, IT specialist, higher education; Narrator 4: man, 70 years old, engineer, higher education; Narrator 5: woman, 64 year old, nurse, higher education; Narrator 6: woman, 70 year old, doctor, higher education; Narrator 7: woman, 65 years old, office worker, secondary education; Narrator 8: woman, 66 years old, teacher, higher education; Narrator 9: woman, 69 years old, office worker, higher education; Narrator 10: woman, 62 years old, teacher, higher education; Narrator 11: man, 71 years old, engineer, higher education; Narrator 12: woman, 62 years old, draftsman, secondary education. 


\section{INTERPRETATION OF THE INFORMATION SOCIETY BY RESPONDENTS}

Scientific articles (Wąsiński, Tomczyk, 2013; Szmigielska, Bąk, Hołda, 2012) and reports (Frąckowicz, 2009) point out that seniors are in the group which is particularly vulnerable to social exclusion. On this basis, it can be concluded that the elderly perceive the new reality as alien and incomprehensible. However, narratives of people who take part in research do not fully confirm this assumption: a positive image of the information society emerges from studied narrative. Participants of this research on information society firstly pointed to its positive aspects, such as the opportunity to travel, helpful and convenient technology, and the ability to learn about other cultures. Comments below show how seniors interpret the information society:

Modern times are very open. This is a big change in the direction of human capabilities, knowledge, freedom of life, freedom of behaviour. We are thinking differently and we can afford it. Despite different cultural constraints, today we can afford to think independently, which to me is of big value. Modernity is the common ideology, which is desirable trend. Development consists of that something is torn out of a canon. And so it is with everything. In painting, the Impressionists was "salon des Refusés". Thus science and the general development are born [Narrator 9].

Information Society reminds me of globalization. Now people are more aware of what is happening in the world. Previously, if I had such awareness, the sooner I might have walked out of that my sense of value. I feel a need to use the new technologies. (...) new technologies have opened a world what interests me. I have my email and facebook, though I'm not on it, I read about it. I regularly read news from different countries, but I don't buy newspapers. I have access to specific articles I want to read online. Everything is available, so I can afford such selectivity. I talk with a son who lives abroad via Skype [Narrator 2].

(...)The world always has been curious, especially now - we have open access to acquire knowledge. This technology allows us to quickly explore the world and wander through distant places using a computer. It is a wonderful thing. No need to get on a plane and visit these places [Narrator 10].

In these narratives the new reality is not identified as a threat. On the contrary, seniors believe that they live in interesting times, where there are many opportunities for development. However, they are critical of the information society because they are aware of risks. Many narrators see new opportunities in the modern world, but they have pragmatic approach and preserve a certain reserve. This pragmatism lies in the fact that seniors benefit from the opportunities of the information society, but to the extent they deem necessary. Participants of research define themselves as "guests" in a virtual reality and thus benefit from some network capabilities (email, Skype, search engines, and e-banking) but they do not "live" in this space. Virtual space and real do not overlap, as is often the case with younger generations. Seniors separate the real life of the network and do not form a network identity, as we can see from the following quotes: 
Work by the computer isn't my hobby- I know what I need so I search for it, but computer games or finding new things online isn't interesting for me. I approach it pragmatically. I think that there are programs I would like to learn but I need somebody who can teach me. I need someone who can slowly explain everything to me [Narrator 6].

I use a computer every day. I like reading news from around the world, I also like reading about flowers. I often use Google to search for news. I don't buy newspapers because everything is online. I have a facebook account because I had the ICT course at the University for Seniors. However, the computer didn't want to take my data and I couldn't use my facebook. My girls helped me with it at home. I also have e-mail and I use it regularly [Narrator 7].

Statements set forth above show that seniors are aware possibilities of the modern world and they try to use them. It is an interesting fact, that the virtual space is not part of their world of life. The Internet is for them instrument which should make their life. easier The interpretation of information society by seniors is created based on the contrast rule. Old time (communism time) is compared with present - on this basis is created a positive interpretation of the modern times:

The world is so changed that without being able to use new technologies it is difficult to function. These skills are necessary because they allow us to connect with the world. Besides, we are living the moment of an open Europe and we can travel wherever we want. In the 80s, I went abroad, to the other side of the Iron Curtain. When I was in West Berlin I was shocked because I had a feeling that from the sad and grey world I went to a colorful one. Later when I went to Paris, I was ready for a change- it wasn't such a shock for me. However I saw two different worlds: one was a communist reality and another one the world of western Europe. Nowadays is the same everywhere - I don't see a difference between Poland and France. We have the same shops, clothes, cars etc. We are in Europe and it is beautiful. I'm very glad for this fact [Narrator 10]. Other narrators also had similar opinions [Narrators: $1,3,6,7,8,9,12]$.

Narratives of seniors showed that the information society is positive according to them. This interpretation is constructed in relation to the past (communist) in which they lived. This fact had a positive impact on the image of the new reality. It is interesting that seniors have a pragmatic approach to the information society - they use its possibilities but only to the extent that is necessary. It is also important to consider the fact that people are aware of the role played by learning to adapt to modern times. Although seniors are positive about the new society, they are not uncritical towards it. Narrators recognize and emphasize the positive aspects of a new reality, but they are also aware of the limitations and even dangers that are associated with it. 


\section{THE CHALLENGES OF THE INFORMATION SOCIETY IDENTIFIED BY OLDER PEOPLE}

Seniors who took part in this research were reflective - they had their own opinions about the challenges of the information society. As previously noted, participants recognized possibilities of modern society but also risks within it. The fact that opportunities were stressed by seniors more often than risks is also worth considering. Table 1 presents categories relating to the challenges of the information society which was revealed in biographies.

Table 1. Challenges of the information society identified by seniors

\begin{tabular}{|c|c|c|}
\hline & $\begin{array}{l}\text { Categories relating to the challenges of the } \\
\text { information society }\end{array}$ & $\begin{array}{l}\text { Narratives in which category } \\
\text { appears }\end{array}$ \\
\hline \multirow{5}{*}{ 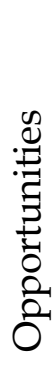 } & Travel freedom & $1,5,6,8,12$ \\
\hline & $\begin{array}{l}\text { The new communication possibilities (skype, } \\
\text { e-mail etc.) }\end{array}$ & $2,3,7,8,9,12$ \\
\hline & Easy access to information and knowledge & $2,4,5,7,8,9,10,11,12$ \\
\hline & Technology which makes life easy & $5,7,9,10,11$ \\
\hline & New possibilities of work & 1,5 \\
\hline \multirow[b]{5}{*}{$\frac{n}{\frac{n}{a n}}$} & The rapid pace of change & $1,3,12$ \\
\hline & Adaptation problems & $1,2,3,4,5,6,7,8,9,10,11,12$ \\
\hline & New technology as danger for privacy & 2,4 \\
\hline & The need (compulsion) of learning & $3,6,7,12$ \\
\hline & $\begin{array}{l}\text { Indirect communication (using ICT) implies } \\
\text { problems in interpersonal relationships }\end{array}$ & 4 \\
\hline
\end{tabular}

Source: own research.

The data presented in the table indicates that seniors analyze the surrounding reality and aptly describe it. They seem aware of the challenges facing modern man. It is interesting that similar categories appear in many narratives. It is also worth noting that the relationship between categories chosen from narratives matched the categories shown in the theoretical part of the article. Common categories for both typologies are:

- Adaptation problems of seniors- it implies the need to take measures to combat e-exclusion;

- The rapid pace of change;

- The need (compulsion) of lifelong learning;

- New type of communication;

- Change of the nature of work.

The category concerning adaptation problems of the elderly appears in all narratives. It is closely linked with the rapid pace of change to which man must adapt, which is presented in the following statements: 
I look at the present day and I feel embarrassed, because I cannot keep up with it. This is what happens in this new reality it is great and enormous, but also terrible. For example, cell phones, computers, which allow you to pass information to the other end of the world, indeed they are a great invention - new technology is great. However, I do not keep up with the rush of it all-it surpasses me. Sometimes I lose track of the development of technology. This situation relates primarily to the elderly, because young people cope well with these changes. The ability to use these technologies is needed, but without exaggeration. I am all for moderation in all things, also in technology and development [Narrator 8].

The development of technology is going too fast, it should be gradual. This should be done gradually over 100 years, because people of my age have problems, especially those over 80 years. I know people who are teachers and can not use a calculator (...) [Narrator 1].

Another category is the need of lifelong learning. In relation to older people learning is only possible through keeping up with changes in the information society. The aim of learning is prevention of social marginalization - three participants of research noted this issue. Older people who do not take up learning technologies are exposed to social marginalization. Therefore, educational activity is a factor dividing the seniors on those who participate in the information society and those who are to some extent excluded from it. This division (seniors learner vs. seniors who are not learning) is perceived by many narrators. Therefore, education as a necessary skill in the information society is one of the categories in those studies. This category will be developed further later in this paper.

Participants of research pointed out that the virtual world is a threat to the privacy of modern man. Seniors note that many of people move private life into virtual space, which is not assessed positively by them. Moreover, seniors also draw attention to the threat from terrorism online. It involves blocking of major websites by hackers, stealing personal data of citizens, as well as stealing from banks. These challenges are understood by participants as a kind of threat that must be countered. However, many challenges were identified by them as opportunities.

Easy access to information and knowledge is the common challenge that usually appears in the narratives. Respondents appreciate the power of the Internet and they use it. This category is particularly important in the context of educational activity of the elderly. The ability to easily and quickly access information and knowledge from various sources is helpful in learning. Researched subjects in their narratives often highlighted the new possibilities of communication. The use of e-mail, instant messaging (e.g. Skype) or networking communities allow contact with people all over the world. This is especially important for people whose relatives and friends live far away. The Internet allows them to easily and freely maintain contact. In this context, they can maintain relationships with relatives through the internet. Easy communication over the internet also allows them to meet people who share similar passions or hobbies. However, one of the narrators drew attention to 
the negative aspect of this type of communication. In his opinion, too frequent use of indirect communication means that people don't meet each other and they cannot chat 'face to face'.

Seniors emphasized the fact that new technologies make life easier. This statement appears in the narratives in which the interpretation of the information society is created on the principle of contrast and references to the past. They consider that in the past some activities (e.g. washing-up, cleaning, and counting) took more time than now. In this context, the progress of technology greatly improved the quality of life, which was noted. The category on new job opportunities also appeared in the narratives. Seniors had thought of the possibility of part-time work, at home via the internet. They also mentioned the fact that they can travel freely. The older generation appreciates this opportunity, especially since in the past, traveling was very limited, and sometimes impossible. This situation changed as a result of the collapse of communism and the Polish accession to the European Union.

Analysis of narratives of seniors shows that they are aware of the challenges that the information society entails. The frequency of the occurrence of the above categories in narratives show which challenges are the most important in the opinion of senior citizens. The relationship between the challenges of the information society and the need for lifelong learning is a noticeable.

\section{EDUCATION AS A NECESSARY SKILL IN THE INFORMATION SOCIETY}

Narrators who took part in the biographical research were educationally active. In the opinion of seniors education is a fundamental element of modern society. However, participants in many narrations created own life stories comparing themselves to other seniors who do not undertake education. Considering the fact that the research was carried out in the interpretative paradigm, the opinion of seniors participating in research about their peers who do not undertake further learning is very interesting in this case. Especially that people who represent certain opinions or observations do it in other perspectives different from the researchers, because they are representatives of that age group. Moreover, the fact that this category appeared in many narratives proves that this is an important aspect of the seniors' world.

No educational activity implies a worse quality of life for these people. Life for these people is considered as more boring and sad: My friends who are retired generally are reluctant to make the effort to go out and learn something new. Their life is slow and sad because when they stay at home all the time and don't have the opportunity to discover the world - so their world is declining. Therefore learning is now critical [Narrator 5].

Moreover, educational activity reduces the risk of social exclusion: A person who learns can move in the world is not lost. She/he is satisfied with her life. I have the 
comparison with my cousin, who has only an elementary school education. He has a good retirement, because he was a dodger all his life. And now when he is retired he does not know what to do, cannot be found - he watches TV all the time. Learning allows a much better life in this world [Narrator 1].

Education requires sacrifices - that's the truth. Older people do not appreciate intellectual development, to thereby predict a variety of life situations, participate in them in a deliberate way [Narrator 9].

A man who does not learn and is not curious vegetates, because curiosity about the world has been forced onto us [Narrator 10].

In the opinion of seniors in modern life ICT skills are very important. People who can not use new technology are excluded from many important aspects of social life. Especially many areas of life which are only accessed through the internet. The following statements of seniors show how important is the ability to use new technologies:

Without technology, you will not be accepted into society. The world has so changed that ICT is necessary for normal life [Narrator 2].

In my opinion, few seniors can handle new technologies and they miss out on a lot of things. I think that age is not a limitation, because if I feel good and I want to keep up, and I feel like it, why should I not try these technological innovations? I feel that I am equal with the young. For seniors keeping up with the changes can be difficult. They restrict themselves to looking for excuses because learning is a difficult challenge [Narrator 5].

I feel the need to use new technologies. It seems to me that man is excluded if he/she does not know how to operate a computer and use the internet. I once had a situation that I asked one of my friends to send me a photo by e-mail. She told me then she did not know how to do it - she was embarrassed that she could not do that (...) [Narrator 2].

Some older people have a problem with the fact that they cannot do some things on their own. They are ashamed about it. For example, I have a friend who has not caught up with the twenty-first century. He is a computer scientist by profession, but worked 30 years ago. He now can not cope with new technologies but he doesn't admit this because he is ashamed. He is backward because he was sluggish to change and now takes it as a discomfort [Narrator 11].

These statements show that a lack of ICT competences affects the mental health of older people - they feel because of this inferior and ashamed of their unawareness. There are many reasons why seniors do not undertake education. Based on the analysis of the narrative it was possible to identify the causes of this phenomenon. Narrators identify the following reasons for the lack of educational activity of other seniors:

- shame resulting from the lack of knowledge and skills:

The problem of the elderly is closing themselves off from the virtual world and the lack of communication. And communication is a prerequisite for survival in modern times. The older generation is ashamed to ask, having a problem with communication (...) [Narrator 6]. 
Older people have a huge problem to learn how to use a computer if they don't have a basic knowledge in this area. For example, my friends pretend that they can use a computer but, in fact, they can not. I know a lot about computers, e-mails etc. and when I ask them about something related to computer I see that they don't know. They pretend that they know but it is not true [Narrator 12].

\section{- focus on the family:}

People often think that it is the duty of parents to take care of their grandchildren and they also believe that it is ok. I think that this is terrible and so wrong. They explain that in this way the grandparents have contact with their grandchildren, but I think it is evident that they are using them for free care. I think that older people should develop their passions and learn [Narrator 11].

Older people have a mental barrier. Some people are so focused on their family problems that can't - I can't say that they don't want to, but they do not really have time to do anything else. They devote themselves totally to their family [Narrator 8].

\section{- diseases of old age:}

In my opinion we should teach people to be open to learning. The willingness to study should be something natural- I think that it's the most important. A lot of older people have such openness, but some do not. It could be result of the disease in older age. For example me, when I have a health problem, I begin to be calm and I withdraw from the world, because it is natural because you have to limit the number of external stimuli in order to accumulate the energy to fight the disease [Narrator 9].

\section{- lack of openness to learn (lack of motivation to learn)}

Some people do not want to learn, they prefer to sit at home and watch TV or sit on the bench. This is their way to vegetate [Narrator 10].

These statements clearly show that even seniors recognize the division between those who participate in social life and those who are marginalized. The basis of this division is educational activity, or the lack thereof. No educational activity that makes the quality of life of seniors is more important. An older person who does not learn, is seen as closed to the world, and his/ her existence is reduced to vegetation. Seniors who are not educationally active are perceived by others as fearful and ashamed of their ignorance. It could be a barrier to undertake learning for them. It is worth noting that the narrators also point to external factors of lack of educational activity of seniors, such as: shame resulting from the lack of knowledge and skills; focus on the family; diseases of old age; lack of openness to learn (lack of motivation to learn).

Narrators' opinions about seniors who are passive educationally show how they perceive their peers and point out reasons of their e-exclusion. Moreover, these reflections inspire us to undertake further scientific exploration in this area. 


\section{CONCLUSION}

Contrary to prevailing belief, not all older people are marginalized in the new reality. Senior citizens positively assess the changes which are the result of the information society and recognize many opportunities for personal development. Therefore, education actually plays an important role, both in the self-development of older people, as well as their adaptation to the information society.

Seniors also proved to be reflective observers of the new reality. The greatest risk identified by the respondents is related to the high pace of change within the the new reality and relates to the adaptation difficulties of older people. The participants of this research are of the opinion that only through continuous learning is it possible to keep up with these changes. In addition to the problems associated with that dynamic change and the need to adapt to this, seniors pointed to the threat of loss of privacy on the Internet or problems with interpersonal communication which takes place via computer or phone. Respondents have noticed a lot of benefits that the information society entails such as: easy and fast access to information and knowledge, freedom to travel, new job opportunities through the Internet, the ability to stay in touch with loved ones, etc.

In this context, we can point to two areas of educational activities that are most significant in the society: using of new technology (ICT), interpersonal skills. It is these areas should be particularly taken into account in designing the educational process directed to the elderly, because they refer to the challenges entailed in the information society. Of course, other competences are important too in the planning of the educational process, however, respondents particularly emphasized the importance of these three areas.

\section{REFERENCES}

[1] (2015). Rocznik Demograficzny [Demographic Yearbook], 58.

[2] Castells, M. (2008)., Społeczeństwo sieci [Rise of the network society]. Warszawa: PWN.

[3] Coldwell, J. C. (2006). Demographic transition theory, Dordrecht: Springer

[4] Dominicé, P. (2006). Uczyć się z życia. Biografia edukacyjna w edukacji dorostych [Learning from life. Biography education in adult education]. Łódź: Wydawnictwo Wyższej Szkoły Humanistyczno-Ekonomicznej.

[5] Frąckiewicz, E. (2009). Wptyw internetu na aktywność seniorów z punktu widzenia strategii budowania spoteczeństwa informacyjnego i2010 [The impact of the Internet on the activity of senior citizens from the point of view of the strategy of building the information society i2010]. Warszawa: Centrum Europejskie Natolin.

[6] Kozielecki, J. (1987). Koncepcja transgresyjna człowieka [The transgressive concept of man]. Warszawa: PWN.

[7] Kucharczyk, J., \& Kuźmicz, E. (2011). Wstęp [Introduction]. In: J. Kucharczyk, E. Kuźmicz (Eds.), Podnoszenie wieku emerytalnego-diagnoza potrzeb i rekomendacje na przykładzie Polski i Niemiec [Raising the retirement age - diagnosis of needs and recommendations on the example of Poland and Germany] (pp. 9-10). Warszawa: Instytut Spraw Publicznych. 
[8] Łuczak, M. (2006). Spoteczeństwo informacyjne jako spoteczeństwo ryzyka [Information Society as a society of risk]. In: L.H. Haber, M. Niezgoda (Eds.), Społeczeństwo informacyjne. Aspekty funkcjonalne $i$ dysfunkcjonalne [Information Society. Functional and dysfunctional aspects]. Kraków: Wydawnictwo Uniwersytetu Jagiellońskiego.

[9] Marcinkiewicz, A. (2014). Edukacja całożyciowa wobec wyzwań społeczeństwa informacyjnego [Lifelong learning facing challenges of information society]. In: E. Skibińska, H. Solarczyk-Szewc, A. Stopińska Pająk (Eds.), Teoria i praktyka edukacji dorostych w procesie zmian [The theory and practice of adult education in the process of change] (pp. 179-192). Warszawa-Bydgoszcz: Akademickie Towarzystwo Andragogiczne, Wyższa Szkoła Gospodarki w Bydgoszczy.

[10] Marcinkiewicz, A., \& Cutter Z. (2014). Transgresyjne uczenie się seniorów w społeczeństwie informacyjnym [Transgressive learning of seniors in the information society], In: I. Paszenda, R. Włodarczyk (Eds.), Transgresje w edukacji [Transgressions in education] (pp. 149-158). Kraków: Oficyna Wydawnicza „Impuls".

[11] Nowak-Starz, G., Markowska, M., Zboina, B., \& Grzywna, T. (2009). Społeczny obraz starości w XXI wieku [Social image of old age in the 21st century]. In: B. Zboina, G. Nowak-Starz (Eds.), Starość: obawy, nadzieje, oczekiwania. Wybrane zagadnienia gerontologii [Old age: fears, hopes and expectations. Selected issues in gerontology] (pp. 17-19). Ostrowiec Świętokrzyski: Stowarzysznie "Nauka Edukacja Rozwój".

[12] Okólski, M. (2004). Demografia zmiany społecznej [Demography of Social Change]. Warszawa: Wydaw. Naukowe Scholar.

[13] Okólski, M. (1997). Demograficzno-instytucjonalne antynomie wspótczesności [Demographic and institutional antinomies of modernity]. In: J. Reykowski, T. Bielicki (Eds.), Dylematy wspótczesnej cywilizacji a natura człowieka [Dilemmas of modern civilization and human nature] (pp. 25-55). Poznań: Zysk i S-ka.

[14] Sienkiewicz, P. (2007). Społeczeństwo „ryzyka”- wielorakie perspektywy [Society of „risk” - the multiplicity of perspectives]. In: M. Gwoździcka-Piotrowska, J. Wołejszko, A. Zduniak (Eds.), Edukacja w społeczeństwie "ryzyka". Bezpieczeństwo jako wartość [Education in the society of "risk". Security as a value]. Poznań: Wydawnictwo Wyższej Szkoły Bezpieczeństwa.

[15] Stuart-Hamilton, I.(2006) Psychologia starzenia się. Wprowadzenie. [Psychology of ageing. An introduction]. Poznań: Zysk i Spółka.

[16] Szmigielska, B., Bąk, A., \& Hołda, M. (2012). Seniorzy jako użytkownicy internetu [Seniors as users of the internet]. Nauka, 2/2012, 141-155.

[17] Sztompka, P. (2002). Socjologia. Analiza społeczeństwa [Sociology. Analysis of society]. Kraków: Znak.

[18] Wąsiński, A., \& Tomczyk, Ł., (2013) (Eds.), Seniorzy w świecie nowych technologii. Implikacje dla praktyki edukacyjnej oraz rozwoju społeczeństwa informacyjnego [Seniors in the world of new technologies. Implications for educational practice and the development of the information society]. Bielsko-Biała: Wyd. Naukow. Śląsk.

[19] World Population Ageing (2013). New York: United Nations.

[20] Zacher, L. W. (2007). Transformacje społeczeństw: od informacji do wiedzy [Transformations of societies: from information to knowledge]. Warszawa: Wydawnictwo C. H. Beck. 